\title{
IMPLEMENTASI PENDIDIKAN KARAKTER DI SMP NEGERI 1 DAN MTS AL-QASIMIYAH KECAMATAN PANGKALAN KURAS KABUPATEN PELALAWAN
}

\author{
Ramli, Wiwik Wijayanti \\ Dinas Pendidikan Kab. Pelalawan, Universitas Negeri Yogyakarta \\ ramlisaja47@yahoo.com
}

\begin{abstract}
Abstrak
Penelitian ini bertujuan untuk mendeskripsikan implementasi pendidikan karakter di SMP Negeri 1 dan MTs Al-Qasimiyah Pangkalan Kuras, Kabupaten Pelalawan. Penelitian ini merupakan penelitian deskriptif dengan pendekatan kualitatif. Subjek penelitian ini adalah kepala sekolah, guru, dan siswa. Data penelitian dikumpulkan melalui wawancara, observasi, dan dokumentasi serta dianalisis secara kualitatif menggunakan teknik analisis data model interaktif Miles and Huberman. Hasil penelitian ini adalah sebagai berikut. 1) Pendidikan karakter di SMP Negeri 1 dan MTs Al-Qasimiyah Pangkalan Kuras dilaksanakan melalui pengintegrasiannya ke dalam mata pelajaran, pengembangan diri, budaya sekolah, dan kegiatan ekstrakurikuler. Sedangkan perbedaannya, di MTs Al-Qasimiyah lebih menitikberatkan pendidikan keagamaan. 2) Faktor penghambat: a) masih ada guru yang belum melaksanakan pendidikan karakter karena kurangnya sosialisasi dan pelatihan; b) masih ada guru yang belum memberikan keteladanan sedangkan di MTs Al-Qasimiyah telah mencerminkan keteladanan yang baik.; c) masih ada orang tua siswa yang kurang peduli terhadap pendidikan anaknya di sekolah terutama siswa yang melanggar tata tertib maupun aturan-aturan sosial.
\end{abstract}

Kata kunci: implementasi, pendidikan karakter

\section{THE IMPLEMENTATION OF CHARACTER EDUCATION IN SMP NEGERI 1 AND AL-QAMISIYAH ISLAMIC JUNIOR HIGH SCHOOL IN PANGKALAN KURAS, PELALAWAN REGENCY}

\begin{abstract}
This research aims to know the implementation of character education in Junior High School 1 and Al-Qamisiyah Islamic Junior High School in Pangkalan Kuras, Pelalawan Regency. This was a descriptive research with the qualitative approach. The subjects were principals, teachers, and students of Junior High school 1 and Al-Qasimiyah Islamic Junior High School in Pangkalan Kuras, Pelalawan Regency. The data were collected thourogh interviews and document studies, and analyzed qualitatively using the technique of interactive analysis model of Miles and Huberman. The results of this research are as follows. 1) Character education in Junior High School 1 and Al-Qasimiyah Islamic Junior High School Pangkalan Kuras, Pelalawan Regency is implemented by integrating it into other subjects, personal development, school culture, and extracurricular activities. The difference is that in Al-Qasimiyah Islamic Junior High School it is more focused on a religious education. 2) The inhibiting factors, among others: a) some teachers do not implement caracter education due to the lack of socialisazion and training, b) there are still teachers in Junior High School 1 who have not provided exemples while the teachers in Al-Qasimiyah Islamic High School have reflected a good example, c) some parents are still not concerned about their students education at school, especially the students who violate rules and social rules.
\end{abstract}

Keywords: implementation, character education 


\section{Pendahuluan}

Pendidikan memegang peranan penting dalam membangun kecerdasan sekaligus kepribadian anak manusia untuk menjadi lebih baik. Oleh karena itu, pendidikan secara terus menerus dibangun dan dikembangkan agar proses pelaksanaannya menghasilkan generasi yang diharapkan. Begitu juga dengan pendidikan di negeri ini, bangsa Indonesia tidak ingin menjadi bangsa yang bodoh dan terbelakang, terutama dalam menghadapi zaman globalisasi yang terus berkembang di era kecanggihan teknologi dan komunikasi. Oleh karena itu, perbaikan sumber daya manusia yang cerdas, terampil, mandiri, dan berakhlak mulia terus di upayakan melalui proses pendidikan, yakni pendidikan berkarakter.

Pendidikan karakter sesungguhnya sudah tercermin dalam Undang-Undang Nomor 20 Tahun 2003 tentang Sistem Pendidikan Nasional pasal 3 mengatakan bahwa: Pendidikan nasional berfungsi mengembangkan kemampuan dan membentuk watak serta peradaban bangsa yang bermartabat dalam rangka mencerdaskan kehidupan bangsa, dan bertujuan untuk berkembangnya potensi peserta didik agar menjadi manusia yang beriman dan bertaqwa kepada Tuhan Yang Maha Esa, berakhlak mulia, sehat, berilmu, cakap, kreatif, mandiri, dan menjadi warga negara yang demokratis serta bertanggung jawab.

Pendidikan karakter merupakan salah satunya upaya perbaikan kualitas pendidikan Indonesia. Gagasan ini muncul karena proses pendidikan yang selama ini dilakukan dinilai belum sepenuhnya berhasil dalam membangun manusia Indonesia yang berkarakter. Penilaian ini didasarkan pada banyaknya para lulusan sekolah yang cerdas secara intelektual, namun tidak bermental tangguh dan berperilaku tidak sesuai dengan tujuan mulia pendidikan.

Perilaku yang tidak sesuai dengan tujuan mulia pendidikan misalnya: tindak pidana korupsi yang ternyata dilakukan oleh orang-orang yang berpendidikan, se- lain itu tingginya angka tindak kekerasan serta perilaku menyimpang remaja yang sudah meresahkan masyarakat seperti dipaparkan dibawah ini: Data Komisi Nasional Perlindungan Anak merilis jumlah tawuran pelajar tahun 2011 sebanyak 339 kasus dan memakan korban jiwa 82 orang. Tahun sebelumnya, jumlah tawuran antarpelajar sebanyak 128 kasus. Tak berbeda jauh, data dari Komisi Perlindungan Anak Indonesia (KPAI) menyebutkan, pengaduan kekerasan kepada anak sebanyak 107 kasus, dengan bentuk kekerasan seperti kekerasan fisik, kekerasan psikis, pembunuhan, dan penganiayaan. Sementara, dari jajak pendapat Kompas pada bulan Oktober 2011, dengan responden di 12 kota di Indonesia, diketahui sebanyak 17,5 persen responden mengakui bahwa saat dia bersekolah SMA, sekolahnya pernah terlibat tawuran antar-pelajar. Tidak sedikit pula responden atau keluarga responden yang mengaku pada masa bersekolah terlibat tawuran atau perkelahian massal pelajar. Jumlahnya mencapai 6,6 persen atau sekitar 29 responden. (http:/ / komnaspa.or.id/Komnaspa/Artikel.html.

Diunduh pada 1 agustus 2012).

Kemajuan suatu bangsa sangat erat kaitannya dengan akhlak dan moral warganya, sebagaimana dikemukakan Lickona (1991: 13-18): Ada 10 indikator tanda-tanda zaman yang harus diwaspadai karena jika tanda-tanda itu sudah ada, berarti sebuah bangsa sedang menuju kehancuran. Tandatanda yang dimaksud adalah: (1) violence and vandalism (2) stealing (3) cheating (4) disresfect for autority (5) peer cruelty (6) bigotry (7) Bad language (8) sexual precocity and abuse (9) increasing self and conteredness and declining civic responsibility (10) selfdestructive behavior.

Saat ini arus globalisasi sudah mencapai pelosok tanah air. Dengan adanya kemajuan yang sangat pesat dibidang teknologi komunikasi eletronik dan komputer, informasi sangat mudah untuk diperoleh dari manapun dalam waktu yang amat singkat. Dampak negatif adalah masuknya nilai-nilai asing yang bertentangan dengan nilai-nilai hukum budaya bangsa yang 
dapat merusak nilai-nilai moral masyarakat. Di kalangan generasi muda khususnya akan melemahkan konsep jati diri sebagai bangsa Indonesia. Hal ini tercermin dalam sikap, perilaku, dan mentalitas, seperti menurunnya toleransi dan tenggang rasa, meningkatnya perilaku-perilaku bermasalah, misalnya penyalagunaan substansi psikoatif, perilaku seks bebas, pemanfaatan waktu luang yang tidak efektif.

Pendidikan tidak hanya mendidik para peserta didik agar menjadi manusia yang cerdas, tetapi juga membangun kepribadiannya agar berakhlak mulia. Salah satu tujuan pendidikan di Sekolah Menengah Pertama (SMP/MTs) adalah pengembangan karakter siswa yang dapat dicapai melalui pengembangan dan implementasi Kurikulum Tingkat Satuan Pendidikan (KTSP) yang mengacu pada standar nasional pendidikan (SNP). Nilai-nilai karakter secara jelas dijabarkan di dalam SNP, Standar Kompetensi Lulusan dan materi yang harus disampaikan, dikuasai, serta direalisasikan oleh peserta didik dalam kehidupan sehari-hari.

Namun saat ini pengembangan dan implementasi Kurikulum Tingkat Satuan Pendidikan (KTSP) masih cenderung terpusat pada pengembangan kemampuan kecerdasan intelektual (kognitif) dan di nilai kurang berhasil dalam membangun kepribadian peserta didik agar berakhlak mulia atau cenderung mengabaikan aspek (afektif) dan (psikomotorik). Pada hal seharusnya pendidikan tidak hanya menghasilkan generasi yang cerdas secara akademik, namun juga berakhlak mulia.

Sementara itu pusat kurikulum kemendiknas (2010: 8-10) menetapkan 18 nilai karakter yang bisa dikembangkan sekolah yakni: religius, jujur, toleransi, disiplin, kerja keras, kreatif, mandiri, demokratis, rasa ingin tahu, semangat kebangsaan, cinta tanah air, menghargai prestasi, bersahabat/komunikatif, cinta damai, gemar membaca, peduli lingkungan, peduli sosial, tanggung jawab.

Nilai-nilai karakter tersebut dikembangkan di SMP Negeri 1 dan MTs AlQasimiyah Pangkalan Kuras, Kabupaten
Pelalawan, Riau. Namun dalam pelaksanaannya nilai karakter yang dikembangkan belum terjabarkan dalam indikator yang refresentatif hal ini menyebabkan kesulitan dalam mengungukur ketercapaiannya. Selain itu sekolah belum dapat memilih nilainilai karakter yang sesuai dengan visinya ditambah lagi jumlah nilai-nilai karakter yang demikian banyak, baik yang diberikan oleh Kementrian Pendidikan dan Kebudayaan, maupun dari sumber-sumber lain sehingga sekolah menghadapi kesulitan dalam memilih nilai karakter mana yang sesuai dengan visi sekolahnya. Hal ini tentunya berdampak pada gerakan membangun karakter di sekolah sehingga menjadi kurang terarah. Sementara itu pemahaman guru tentang konsep pendidikan karakter yang masih belum menyeluruh karena kurangnya sosialisasi pada semua guru dengan baik sehingga mereka belum memahaminya, guru juga belum memiliki kompetensi yang memadai untuk mengintegrasikan nilai-niai karakter pada mata pelajaran yang diampunya.

Berdasarkan observasi yang dilakukan selama 2 bulan yaitu antara bulan September sampai dengan Oktober 2012 di SMP Negeri 1 dan MTs Al-Qasimiyah Pangkalan Kuras, Kabupaten Pelalawan Riau di ketahui kondisinya bahwa: SMP Negeri 1 Pangkalan Kuras telah melaksanakan 18 nilai karakter menurut kemendiknas melalui pengintegrasian ke dalam semua mata pelajaran, proses pembelajaran, pengembangan diri, dan budaya sekolah, namun hasilnya belum optimal. Hal ini dapat dilihat dengan masih adanya siswa yang merokok di lingungan sekolah, siswa datang terlambat, dan mencotek. Belum optimalnya hasil pelaksanaan pendidikan karakter juga tidak terlepas dari faktor kepala sekolah dan guru dalam menerapkan pendidikan karakter kepada siswa, seperti kurangnya motivasi dan pemahaman kepala sekolah, guru-guru tentang pendidikan karakter di sekolah. Sementara itu dinas pendidikan kabupaten sebagai perpanjangan tangan menteri pendidikan nasional di daerah kurang mengadakan sosialisasi pendidikan karakter ke 
sekolah-sekolah, sehingga para guru di SMP Negeri 1 Pangkalan Kuras melaksanakan pendidikan karakter dengan caranya masing-masing dan bahkan masih ada guru yang belum melaksanakan pendidikan karakter.

Kondisi tersebut berbeda dengan pelaksanaan pendidikan karakter di MTs Al-Qasimiyah Pangkalan Kuras, sebagai sekolah madrasah berbasis Islam maka pendidikan akhlak siswa selama ini berjalan baik dengan sistemnya sendiri. Artinya jauh sebelum pendidikan karakter diterapkan oleh pemerintah, MTs Al-Qasimiyah telah mengembangkan pendidikan karakter kepada siswa melalui pengembangan akhlak menurut ajaran agama Islam. Namun dengan diterapkannya pendidikan karakter saat ini, maka para guru harus menyesuaikan pola dan cara pendidikan karakter sesuai dengan pedoman yang telah dibuat oleh pemerintah. Hal ini membuat sebagian guru mengalami kesulitan khususnya dalam mengintegrasikan ke dalam mata pelajaran melalui RPP dan Silabus.

Sebagai bagian dari lembaga pendidikan di Indonesia, MTs Al-Qasimiyah dalam mengembangkan pendidikan karakter belum terprogram secara terintegrasi dengan mata pelajaran. Kurangnya sosialisasi dari dinas terkait membuat beberapa guru belum memahami bagaimana strategi pengembangan dan penerapan pendidikan karakter, sehingga terlihat guru dalam menerapkan pendidikan karakter sesuai dengan pengetahuan dan pemahaman masing-masing.

Peran orang tua dan lingkungan dalam menunjang keberhasilan pendidikan karakter juga sangat menentukan. Pola didik di rumah dan lingkungan yang baik dapat menunjang sekolah dalam mengembangkan pendidikan karakter siswa. Kurangnya peran orang tua dalam membentuk karakter anak disebabkan oleh kesibukan dan pekerjaan orang tua, sehingga tingkat perhatian dan kepedulian terhadap pendidikan karakter di rumah masih belum optimal. Orang tua menganggap bahwa pendidikan secara keseluruhan telah diserahkan sepenuhnya kepada pihak sekolah. Padahal pendidikan adalah tanggung jawab semua pihak masyarakat, keluarga dan sekolah.

Kurang optimalnya pendidikan karakter di MTs Al-qasimiyah Pangkalan Kuras, dapat dilihat dengan masih adanya siswa yang berbicara kurang sopan kepada guru maupun siswa dan kurang disiplin. Di sisi lain, pemahaman sebagian guru dalam mengimplementasikan pendidikan karakter masih kurang dan belum optimal.

Memperhatikan beberapa hal di atas maka melalui penelitian ini akan di kaji lebih mendalam tentang implementasi 18 nilai karakter dan faktor-faktor kendala di SMP Negeri 1 dan MTs Al-Qasimiyah di Kecamatan Pangkalan Kuras, Kabupaten Pelalawan, Riau.

\section{Pengertian Karakter}

Secara etimologis karakter diambil dari bahasa Yunani, karakter berarti to mark atau menandai dan memfokuskan bagaimana mengaplikasikan nilai kebaikan dalam bentuk tindakan atau tingkah laku seseorang. Kemudian istilah ini banyak digunakan dalam bahasa Perancis caratere pada abad 14 dan kemudian masuk ke dalam bahasa Inggris character, yang akhirnya menjadi bahasa Indonesia karakter.

Sedangkan menurut Pusat Bahasa Depdiknas dalam buku panduan pendidikan karakter di Sekolah Menengah Pertama (2010: 12) bahwa: Karakter adalah bawaan, hati, jiwa, kepribadian, budi pekerti, perilaku, personalitas, sifat, tabiat, temperamen, watak. Adapun berkarakter adalah berkepribadian, berperilaku, bersifat, bertabiat, dan berwatak. Individu yang berkarakter baik atau unggul adalah seseorang yang berusaha melakukan hal-hal yang terbaik terhadap Tuhan Yang Maha Esa, dirinya, sesama, lingkungan, bangsa dan negara serta dunia internasional pada umumnya dengan mengoptimalkan potensi (pengetahuan) dirinya dan disertai dengan kesadaran, emosi dan motivasinya (perasaannya). 
Karakter juga erat kaitannya dengan perilaku seseorang yang berbudi luhur dan dilakukan secara terus menerus sebagaimana dikatakan Roberta (1997) mengatakan bahwa karakter adalah: "Character is defined here as the regular display of virtuous behavior. A person can be said to possess a character trait when that person's behavior consistently reflects that trait". Karakter merupakan tampilan biasa mengenai perilaku seseorang yang berbudi luhur, apabila seseorang mencerminkan perilaku itu secara konsisten maka itulah karakter.

Sementara itu menurut pengembangan pendidikan budaya dan karakter bangsa, Kemendiknas(2010: 3) mengatakan: Karakter adalah watak, tabiat, akhlak, atau kepribadian seseorang yang terbentuk dari hasil internalisasi berbagai kebajikan (virtues) yang diyakini dan digunakan sebagai landasan untuk cara pandang, berpikir, bersikap, dan bertindak. Karakter juga dapat dipahami sebagai sifat, watak, tabiat, budi pekerti, atau akhlak yang dimiliki oleh seseorang dan merupakan ciri khas yang dapat membedakan perilaku atau tindakan dan perbuatan antara yang satu dengan lainnya.

Meskipun karakter memang berada di relung hati paling dalam sisi batin manusia, namun karakter dapat terlihat atau terdeteksi karena dapat ditampakkan oleh seseorang lewat perilakunya seharihari. Sementara itu menurut Pritchard dalam Darmiyati Zuchdi dkk (2011: 27) mengatakan: "Karakter adalah sesuatu yang berkaitan dengan kebiasaan hidup individu yang bersifat menetap dan cenderung positif". Sementara itu menurut Dirjen Dikti (Barnawi \& M. Arifin, 2012: 21) mendefinisikan: Karakter sebagai nilai-nilai yang khas-baik (tahu nilai kebaikan, mau berbuat baik, nyata berkehidupan baik, dan berdampak baik terhadap lingkungan) yang terpateri dalam diri dan terjawantahkan dalam perilaku. Karakter secara koheren memancar dari hasil olah pikir, olah hati, olah raga, serta olah rasa dan karsa seseorang atau sekelompok orang. Karakter merupakan ciri khas seseorang atau sekelompok orang yang mengandung nilai, kemampuan, kapasitas moral, dan ketegaran dalam menghadapi kesulitan dan tantangan.

Dari beberapa pengertian diatas dapat di simpulkan bahwa karakter adalah keseluruhan yang tampak dari dalam diri seseorang yang di wujudkan dalam sikap dan perbuatan kesehariannya. Sedangkan karakter mulia adalah seseorang yang selalu ingin berbuat kebaikan pada dirinya dan orang lain.

\section{Pengertian Pendidikan Karakter}

Menurut Dharma Kusuma dkk (2011: 5-6) mendefinisikan pendidikan karakter dalam seting sekolah sebagai: Pembelajaran yang mengarah pada penguatan dan pengembangan perilaku anak secara utuh yang didasarkan pada suatu nilai tertentu yang dirujuk oleh sekolah defenisi ini mengandung makna 1) Pendidikan karakter merupakan pendidikan yang terintegrasi dengan pembelajaran yang yang terjadi pada semua mata pelajaran; 2) diarahkan pada penguatan dan pengembangan perilaku anak secara utuh dengan asumsi anak sebagai organisme manusia yang memiliki potensi unik dikuatkan dan dikembangkan; 3) penguatan dan pengembangan perilaku didasari oleh nilai yang dirujuk oleh sekolah (lembaga).

Pendidikan karakter sangat diperlukan dalam mengembangkan keterampilan seseorang baik dalam membuat keputusan maupun memilih berbagai hal dalam kehidupan, misalnya: pekerjaan, persahabatan, penggunaan waktu luang, kesehatan, penggunaan uang dan kehidupan beragama. Pendidikan karakter bukanlah pendidikan agama, sebagaimana menurut Lahey (2013) mengatakan: "Character education is not old-fashioned, and it's not about bringing religion in to the classroom. Character education teaches children how to make wise decisions and act on them. Character is the "X factor" that experts in parenting and education have deemed integral to success, both in school and in life". 
Maksud dari pernyataan di atas bahwa pendidikan karakter bukanlah suatu yang kuno, dan itu bukan tentang membawa agama ke dalam kelas dimana pendidikan karakter mengajarkan anak bagaimana membuat suatu keputusan yang bijaksana dan melaksanakannya dengan baik. Karakter adalah "faktor X" yang ahli dalam pengasuhan dan pendidikan telah dianggap bagian integral dari kesuksesan, baik di sekolah dan dalam kehidupan. Hal ini menunjukan bahwa dimensi perilaku kemanusian yang mencakup tiga hal paling mendasar yaitu, (1) dimensi afektif yang tercermin pada kualitas keimanan, ketakwaan, dan kompetensi estetis, (2) dimensi kognitif yang tercermin pada intelektualitas untuk menggali, mengembangkan serta menguasai ilmu pengetahuan dan teknologi, (3) dimensi psikomotorik yang tercermin pada kemampuan mengembangkan keterampilan teknis, kecakapan praktis, dan kompetensi motorik.

Berdasarkan beberapa paparan di atas dapat ditegaskan bahwa pendidikan karakter merupakan upaya-upaya yang dirancang dan dilaksanakan secara sistematis untuk menanamkan nilai-nilai perilaku peserta didik yang berhubungan dengan Tuhan Yang Maha Esa, diri sendiri, sesama manusia, lingkungan, dan kebangsaan yang terwujud dalam pikiran, sikap, perasaan, perkataan, dan perbuatan yang berdasarkan norma-norma agama, hukum, tata krama, budaya, dan adat istiadat.

\section{Tujuan Pendidikan Karakter}

Pendidikan karakter pada intinya bertujuan membentuk bangsa yang tangguh, kompetitif, berakhlak mulia, bermoral, bertoleran, bergotong-royong, berjiwa patriotik, berkembang dinamis, berorientasi ilmu pengetahuan dan teknologi yang semuanya dijiwai oleh iman dan takwa kepada Tuhan yang Maha Esa berdasarkan Pancasila.

Menurut Dharma Kusuma dkk (2011: 9) bahwa tujuan pendidikan karakter dalam seting sekolah adalah: 1) menguat- kan dan mengembangkan nilai-nilai kehidupan yang dianggap penting dan perlu sehingga menjadi kepribadian/ kepemilikan peserta didik yang khas sebagai mana nilai-nilai yang dikembangkan; 2) mengoreksi perilaku peserta didik yang tidak bersesuaian dengan nilai-nilai yang dikembangkan oleh sekolah; 3) membangun koneksi yang harmoni dengan keluarga dan masyarakat dalam memerankan tanggung jawab pendidikan karakter secara bersama.

Pada prinsipnya pendidikan selain untuk membentuk manusia yang cerdas juga menjadikan manusia berakhlak mulia dan berkarakter. Sebagaimana dikatakan Foerster dalam Doni Koesoema (2010: 42): Tujuan pendidikan adalah untuk pembentukan karakter yang terwujud dalam satu kesatuan esensial antara si subjek dengan perilaku dan sikap hidup yang dimilikinya. Karakter merupakan sesuatu yang mengkualifikasi seseorang pribadi yang memberikan kesatuan dan kekuatan atas keputusan yang diambilnya.

Menurut panduan pendidikan karakter, Kemendiknas (2010: 7) menyebutkan tujuan pendidikan budaya dan karakter bangsa adalah: (1) mengembangkan potensi $\mathrm{kalbu} /$ nurani/afektif peserta didik sebagai manusia dan warganegara yang memiliki nilai-nilai budaya dan karakter bangsa; (2) mengembangkan kebiasaan dan perilaku peserta didik yang terpuji dan sejalan dengan nilai-nilai universal dan tradisi budaya bangsa yang religius; (3) menanamkan jiwa kepemimpinan dan tanggung jawab peserta didik sebagai generasi penerus bangsa; (4) mengembangkan kemampuan peserta didik menjadi manusia yang mandiri, kreatif, berwawasan kebangsaan; dan (5) mengembangkan lingkungan kehidupan sekolah sebagai lingkungan belajar yang aman, jujur, penuh kreativitas dan persahabatan, serta dengan rasa kebangsaan yang tinggi dan penuh kekuatan (dignity). 
Nilai- nilai Karakter untuk SMP/MTs

Berdasarkan kajian nilai-nilai agama, norma-norma sosial, peraturan/hukum dan prinsip-prinsip HAM, telah terindetifikasi 80 butir nilai karakter yang dikelompokkan menjadi lima, yaitu Nilai karakter dalam hubungannya dengan (1) Tuhan Yang Maha Esa, (2) diri sendiri, (3) sesama manusia dan (4) lingkungan, serta (5) kebangsaan. Namun demikian, penanaman kedelapanpuluh nilai tersebut merupakan hal yang sangat sulit. Oleh karena itu pada tingkat SMP dipilih 20 nilai karakter utama yang disarikan dari butirbutir SKL dan SK/KD. Adapun nilai tersebut sebagai berikut (Kemendiknas, 2010: 16-19):

1. Nilai karakter dalam hubungannya dengan Tuhan (Religius).

2. Nilai karakter dalam hubungannya dengan diri sendiri
a. Jujur
b. Bertanggung jawab
c. Bergaya hidup sehat
d. Disiplin
e. Kerja keras
f. Percaya diri
g. Berjiwa wirausaha
h. Berpikir logis, kritis, kreatif, dan inovatif
i. Mandiri
j. Ingin tahu
k. Cinta ilmu

3. Nilai karakter dalam hubungannya dengan sesama
a. Sadar akan hak dan kewajiban diri dan orang lain
b. Patuh pada aturan-aturan sosial
c. Menghargai karya dan prestasi orang lain.
d. Santun
e. Demokratis

4. Nilai karakter dalam hubungannya dengan lingkungan.

5. Nilai kebangsaan

a. Nasionalis

b. Menghargai keberagaman

Sementara itu nilai-nilai yang dikembangkan dalam pendidikan budaya dan karakter bangsa di identifikasi dari sumber-sumber berikut ini: agama, pancasila, budaya dan tujuan pendidikan nasional. Berdasarkan keempat sumber nilai itu teridentifikasi sejumlah nilai yang dapat dikembangkan melalui pendidikan budaya dan karakter bangsa. (Kemendiknas, 2010: 8-10) sebagai berikut: (1) religius (2) jujur (3) toleransi (4) disiplin (5) kerja keras (6) kreatif (7) mandiri (8) demokratis (9) rasa ingin tahu (10) semangat kebangsaan (11) cinta tanah air (12) menghargai prestasi (13) bersahabat/komunikatif (14) cinta damai (15) gemar membaca (16) peduli lingkungan (17) peduli sosial (18) tanggung jawab.

Nilai-nilai di atas beserta deskripsinya dapat dilihat pada tabel 1 dibawah ini, dengan melihat dari nilai-nilai diatas sekolah mempunyai peranan yang sangat besar sebagai pusat pendidikan dan pembudayaan karakter.

Dari semua nilai-nilai karakter di atas dan implementasinya di sekolah jumlah dan jenis karakter yang dipilih tentu akan dapat berbeda antara satu daerah atau sekolah yang satu dengan yang lain. Hal itu tergantung pada kepentingan dan kondisi satuan pendidikan masingmasing. Di antara berbagai nilai yang dikembangkan, dalam pelaksanaannya dapat dimulai dari nilai yang esensial, sederhana, dan mudah dilaksanakan sesuai dengan kondisi masing-masing sekolah/wilayah.

\section{Metode Penelitian}

Jenis Penelitian

Penelitian ini menggunakan metode penelitian kualitatif dengan jenis fenomenologi karena penelitian ini mengungkap tentang fakta dibalik fenomena pendidikan karakter di SMP Negeri 1 dan MTs Al-Qasimiyah Pangkalan Kuras dan faktor yang menjadi kendala dalam mengimplementasikan pendidikan karakter secara mendalam.

\section{Waktu dan Tempat Penelitian}

Penelitian dilakukan di SMP Negeri 1 yang beralamat di Jl. Datuk Laksamana 
No 47 Sorek Satu dan MTs Al-Qasimiyah Kecamatan Pangkalan yang beralamat Jl. Amalia No 01 Kelurahan Sorek Satu Pelalawan, Riau.

Penelitian dilaksankan di SMP Negeri 1 dan MTs Al-Qasimiyah Pangkalan Kuras selama empat bulan pada bulan Januari hingga April 2013. Alokasi waktu itu digunakan untuk mengumpulkan data hingga memperoleh data yang lengkap sesuai kebutuhan penelitian.

\section{Subjek Penelitian}

Subjek penelitian ini adalah kepala sekolah, wakil kepala sekolah, guru dan siswa SMP Negeri 1 dan MTs Al-Qasimiyah. Kepala sekolah sebagai pimpinan lembaga diasumsikan mengetahui banyak informasi tentang implementasi pendidikan karakter yang meliputi 18 nilai karakter dan dijadikan sebagai key informan.

Teknik Pengumpulan Data

\section{Wawancara}

Teknik wawancara digunakan untuk menggali data tentang implementasi pendidikan karakter yang meliputi delapan belas nilai karakter. Informasi pelaksanaan pendidikan karakter tersebut diperoleh dari para informan yaitu kepala sekolah, wakasek, guru, dan siswa SMP Negeri 1 dan kepala MTs, wakasek, guru serta siswa MTs Al-Qasimiyah.

\section{Observasi}

Observasi dilakukan untuk mengamati kondisi fisik dan nonfisik, kondisi fisik yang diamati antara lain sekolah, perpustakaan, masjid, ruang kelas, dan sarana penunjang pendidikan karakter lainnya. Sedangkan kondisi nonfisik yang di amati diantaranya perilaku siswa di sekolah. Selanjutnya dari hasil pengamatan dicatat hal-hal penting terkait pengumpulan data penelitian.

\section{Analisis dokumen}

Di dalam melaksanakan metode dokumentasi peneliti menyelidiki bendabenda tertulis, seperti buku-buku, majalah, silabus, RPP, notula rapat, dan catatan harian dan dokumen lain yang berkaitan dengan pendidikan karakter

\section{Teknik Keabsahan Data}

Demi memperoleh data yang valid dan dapat dipertanggungjawabkan secara ilmiah, maka data-data yang dikumpulkan diperiksa keabsahan datanya. Uji keabsahan data pada penelitian kualitatif terdiri dari uji credibility (validitas internal), uji transferability (validitas eksternal), uji dependability (reliabilitas), dan confirmability (objektivitas).

\section{Teknik Analisis Data}

Dalam penelitian kualitatif analisis data yang digunakan bersifat induktif, yaitu analisis berdasarkan data yang diperoleh untuk menemukan konsep dari fokus penelitian yang diteliti. Analisis data pada penelitian ini terdiri dari tiga tahapan yaitu reduksi data, penyajian data, dan penarikan kesimpulan/verifikasi. Senada dengan ungkapan Miles \& Huberman (1994: 10) we define analysis as consisting of three concurrent flows of activity: data reduction, data display, and conclusion drawing/ verification.

\section{Hasil Penelitian dan Pembahasan}

Pendidikan karakter di SMP Negeri 1 Pangkalan Kuras

Religius

Pendidikan karakter religius di SMP Negeri 1 Pangkalan Kuras dikembangkan melalui terintegrasi ke dalam mata pelajaran, kegiatan ekstrakurikuler dan kegiatan rutin. Dalam proses belajar mengajar di kelas dilakukan berdoa sebelum dan sesudah belajar. Selain itu dalam kegiatan ekstrakurikuler dikembangkan melalui belajar Al-Qur'an, dan manasik haji. Untuk kegiatan rutin dilakukan sholat zuhur berjamaah, dan baca yasin di kelas setiap jumat pagi. Nilai religius tidak hanya di kembangkan dalam bentuk ritual tetapi siswa dibiasakan untuk 
berinfak melalui organisasi siswa (OSIS) disaat ada musibah yang menimpa salah seorang warga sekolah. Kondisi ini sesuai dengan nilai-nilai religius yaitu sikap dan perilaku siswa yang patuh dalam melaksanakan ajaran agama yang dianutnya, toleran terhadap pelaksanaan ibadah agama lain, serta hidup rukun dengan pemeluk agama lain.

Jujur

Nilai kejujuran siswa di SMP Negeri 1 Pangkalan Kuras dilakukan melalui pembelajaran di dalam maupun di luar kelas, salah satunya adalah pelarangan mencontek. Namun perilaku tidak jujur masih dilakukan oleh sebagian siswa, hal ini ditunjukkan dengan masih ada siswa yang mencontek ulangan maupun tugastugas lain serta ketidakjujuran dalam melakukan pembelian di kantin sekolah.

Disisi lain nilai kejujuran siswa terhadap barang-barang yang ditemukan di sekolah masih tinggi. Hal ini ditunjukkan dengan banyaknya siswa yang melaporkan dan memberikan barang temuan kepada pihak sekolah. Kantin kejujuran merupakan salah satu indikator keberhasilan sekolah dalam membina dan melatih kejujuran siswa. Namun SMP Negeri 1 Pangkalan Kuras belum menyediakan kantin kejujujuran sebelum tingkat kejujuran siswa baik. Untuk itu pihak sekolah terus berupaya menyadarkan dan memberikan bimbingan kepada siswa-siswi untuk selalu berbuat jujur.

\section{Toleransi}

Nilai toleransi di SMP Negeri 1 Pangkalan Kuras telah di kembangkan. sekolah selalu menghargai dan memberikan perlakuan yang sama terhadap seluruh warga sekolah tanpa membedakan suku, agama, ras, golongan, status sosial, status ekonomi, dan kemampuan khas. Dalam pembelajaran di kelas guru menciptakan suasana keakraban antara sesama siswa dengan belajar kelompok. Sekolah juga memberikan kebebasan untuk melaksanakan ibadah bagi nonmuslim dengan mem- fasilitasi siswa untuk belajar agama melalui pengurus gereja.

Hal ini sesuai dengan nilai-nilai toleransi ialah sikap dan tindakan yang menghargai perbedaan agama, suku, etnis, pendapat, sikap, dan tindakan orang lain yang berbeda dari dirinya.

\section{Disiplin}

Penerapan disiplin siswa di SMP Negeri 1 Pangkalan Kuras telah dilaksanakan oleh pihak sekolah. Kepala sekolah tegas dalam menegakan peraturan sekolah terutama kepada disiplin siswa. Untuk menegakkan disiplin, sekolah telah memiliki tata tertib yang wajib di taati oleh siswa. Tetapi dalam pelaksanaannya masih ada siswa yang melanggar tata tertib sekolah. Sangsi diberikan kepada siswa yang melanggar tata tertib sesuai dengan tingkat dan jenis pelanggaran.

Kehadiran guru yang tepat waktu merupakan contoh kedisiplinan yang ditunjukan guru kepada siswa. Selain itu sebelum kegiatan belajar mengajar di kelas guru memeriksa kerapian, kelengkapan pakaian seragam, dan kebersihan siswa. Apabila siswa sering melanggar tata tertib maka diserahkan kepada guru bimbingan konseling untuk dilakukan pembinaan. Hal ini sesuai dengan nilai-nilai disiplin yaitu tindakan yang menunjukkan perilaku tertib dan patuh pada berbagai ketentuan dan peraturan.

\section{Kerja Keras}

Pendidikan kerja keras sudah dilaksanakan di SMP Negeri 1 Pangkalan Kuras. Guru senantiasa mendorong dan memberikan motivasi kepada siswanya agar senantiasa kerja keras dan berupaya sungguh-sungguh dalam mengatasi berbagai hambatan belajar dan menyelesaikan tugas dengan sebaik-baiknya. Salah satu hasil nilai kerja keras siswa dapat dilihat dengan banyaknya piala atas prestasi yang telah diraih. Namun demikian, masih ada siswa yang malas dan enggan bekerja keras. Untuk itu SMP Negeri 1 Pangkalan Kuras terus memberikan motivasi kepada 
siswa bahwa apabila ingin sukses harus kerja keras dan berdo'a.

Nilai kerja keras telah diintegrasikan ke dalam semua mata pelajaran. Salah satunya dengan pemberian tugas baik secara perorangan maupun kelompok. Selain itu, untuk memotivasi siswa supaya bekerja keras sekolah memasang sloganslogan yang dipasang di tempat strategis di lingkungan sekolah.

Kreatif

Pengembangan nilai kreatif, telah dilakukan di SMP Negeri 1 Pangkalan Kuras. Dalam proses pembelajaran dilakukan melalui pembelajaran praktikum, pemberian tugas mandiri, dan kerja kelompok serta tersedianya papan mading sebagai tempat penuangan hasil kreativitas siswa. Kondisi ini sesuai dengan nilai-nilai kreatif yaitu berpikir dan melakukan sesuatu untuk menghasilkan cara atau hasil baru dari sesuatu yang telah dimiliki dengan demikian siswa bisa menambah pengetahuan dan mengembangkannya menjadi sesuatu yang bermanfaat bagi dirinya dan orang lain.

\section{Mandiri}

Pendidikan nilai mandiri siswa di SMP Negeri 1 Pangkalan Kuras telah dilaksanakan melalui pemberian tugas mandiri, kelompok, pekerjaan rumah, merupakan nilai-nilai yang diintegrasikan ke dalam mata pelajaran. Nilai-nilai mandiri telah dikembangkan di SMP Negeri 1 Pangkalan Kuras khususnya guru mata pelajaran dengan tujuan agar siswa mempunyai tanggung jawab sendiri tidak ketergantungan dengan orang lain. kondisi ini sesuai dengan nilai-nilai mandiri yaitu sikap dan perilaku yang tidak mudah tergantung pada orang lain dalam menyelesaikan tugas-tugas.

\section{Demokratis}

Pendidikan karakter demokratis di SMP Negeri 1 Pangkalan Kuras dikembangkan dalam berbagai kegiatan diantaranya pemilihan pengurus kelas secara terbuka, pemilihan pengurus OSIS, pengurus pramuka. Semua siswa diminta untuk memberikan suara dalam pemilihan tersebut. Selanjutnya nilai demokratis juga di kembangkan dalam belajar kelompok, siswa diminta mengeluarkan pendapat dan saran atas hasil kerja kelompok temannya dan tidak boleh menyanggah temannya yang lagi berbicara, dengan demikian selain nilai demokratis juga dikembangkan nilai percaya diri. Hal ini sesuai dengan nilai-nilai demokratis yaitu cara berpikir, bersikap, dan bertindak yang menilai sama hak dan kewajiban dirinya dan orang lain.

Ingin Tahu

Pengembangan nilai ingin tahu siswa telah dilaksanakan di SMP Negeri 1 Pangkalan Kuras dengan menyediakan sarana dan media komunikasi dan informasi baik media cetak maupun media elektronik serta memfasilitasi warga sekolah untuk berekspolorasi dalam pendidikan, ilmu pengetahuan, teknologi, dan budaya. Selain itu sarana laboratorium komputer, laboratorium bahasa dan perpustakaan juga menunjang rasa ingin tahu siswa. Dalam proses pembelajaran di kelas guru menggunakan metode pembelajaran aktif. Hal ini sesuai dengan nilai-nilai rasa ingin tahu yaitu sikap dan tindakan yang selalu berupaya untuk mengetahui lebih mendalam dan meluas dari sesuatu yang dipelajari, dilihat, dan didengar.

\section{Semangat Kebangsaan}

Nilai semangat kebangsaan di SMP Negeri 1 Pangkalan Kuras dikembangkan melalui kegiatan rutin sekolah dengan melaksanakan upacara bendera setiap hari Senin, serta memperingati hari-hari besar kenegaraan seperti: tanggal 17 Agustus, 2 Mei dan hari pahlawan seta hari-hari besar lainnya. Pelaksanaan upacara hari Senin dilaksanakan pukul 7:30 Wib. Seluruh siswa, guru dan wajib mengikuti sedangkan bagi siswa yang terlambat wajib membuat barisan baru yang terpisah dari barisan kelasnya. 
Cinta Tanah Air

Nilai cinta tanah air di SMP Negeri 1 Pangkalan Kuras di kembangkan melalui keteladanan yang dilakukan kepala sekolah, guru. Seluruh warga sekolah diwajibkan menggunakan bahasa Indonesia yang baik dan benar. Selain itu sekolah juga memasang simbol-simbol negara seperti foto presiden dan wakil presiden, pancasila, peta Indonesia, propinsi, dan kabupaten di setiap kelas. Hal ini sesuai dengan nilai-nilai cinta tanah air yaitu cara berpikir, bersikap, dan berbuat yang menunjukkan kesetiaan, kepedulian, dan penghargaan yang tinggi terhadap bahasa, lingkungan fisik, sosial, budaya, ekonomi, dan politik bangsa.

\section{Menghargai Prestasi}

Nilai karakter menghargai karya dan prestasi orang lain di SMP Negeri 1 Pangkalan Kuras sudah dilaksanakan. Pelaksanaannya dikembangkan melalui terintegrasi ke dalam mata pelajaran. Nilai menghargai karya dan prestasi siswa dikembangkan guru dengan memberikan keteladanan terhadap siswa seperti; memeriksa dan mengembalikan hasil pekerjaan siswa, bagi siswa yang mendapat nilai baik guru memuji hasil kerja siswa dan mengucapkan kata terima kasih, bagus, hebat, dan lain sebagainya. Namun bagi siswa yang belum mendapat nilai baik guru memberikan motivasi dengan mengucapkan kata-kata yang tidak menyinggung perasaan atas hasil pekerjaan siswa.

Sekolah akan memberikan penghargaan dan ucapan selamat kepada peserta yang telah selesai mengikuti lomba. Dimana setelah selesai pelaksanaan upacara bendera Senin pagi akan diumumkan prestasi yang telah diraih utusan sekolah kemudian diikuti ucapan selamat oleh kepala sekolah, guru dan seluruh rekan-rekan siswa. Selain itu sekolah juga memajang hasil prestasi yang telah diraih siswa dengan tujuan agara siswa lain termotivasi.

Hal ini sesuai dengan nilai-nilai menghargai prestasi yaitu sikap dan tindakan yang mendorong dirinya untuk menghasilkan sesuatu yang berguna bagi masyarakat, mengakui, dan menghormati keberhasilan orang lain.

\section{Bersahabat/Komunikatif}

Nilai bersahabat/ komunikatif di SMP Negeri 1 Pangkalan Kuras dikembangkan dengan keteladanan yang dilakukan kepala sekolah, guru dan pegawai tata usaha dengan rasa senang berbicara, bergaul dan bekerjasama. Keteladanan yang dilakukan guru dengan berbicara santun dan penuh keakraban serta penuh kasih sayang kepada semua siswa. guru mau menerima keluhan-keluhan yang disampaikan siswa baik masalah pelajaran maupun masalah diluar pelajaran untuk kemajuan perkembangan siswa. Hal ini sesuai dengan nilai-nilai bersahabat atau komunikatif yaitu tindakan yang memperlihatkan rasa senang berbicara, bergaul, dan bekerja sama dengan orang lain.

\section{Cinta Damai}

Nilai cinta damai di SMP Negeri 1 Pangkalan Kuras dikembangkan melalui terintegrasi ke dalam mata pelajaran. Mata pelajaran yang mengajarkan nilai cinta damai diantaranya PKn, agama, bahasa Indonesia. Selain itu sekolah juga menanamkan kesadaran kepada semua siswa agar selalu menjaga kedamaian seperi menghindari tawuran. Nilai cinta damai juga termasuk ke dalam peraturan tata tertib sekolah. Siswa yang melakukan keributan atau perkelahian akan mendapatkan sangsi dan dilakukan pembinaan oleh guru bimbingan konseling. Selain dari internal sekolah nilai cinta damai juga mendapat dukungan dari pihak luar sekolah misalnya pihak kepolisian yang selalu memberikan sosialisai kepada warga sekolah. Kondisi ini sesuai dengan nilai-nilai cinta damai yaitu sikap, perkataan, dan tindakan yang menyebabkan orang lain merasa senang dan aman atas kehadiran dirinya. 
Gemar Membaca

Nilai gemar membaca di SMP Negeri 1 Pangkalan Kuras dikembangkan melalui program gemar membaca. Untuk menunjang nilai gemar membaca sekolah menyediakan fasilitas perpustakaan dan selalu berusaha menambah jumlah dan jenis buku. Selain itu siswa bisa membaca buku-buku yang disediakan oleh mobil perpustakaan keliling dari Pemerintah Daerah Kabupaten Pelalawan. Selain gemar membaca, nilai cinta ilmu juga dikembangkan dalam proses pembelajaran. Dimana siswa diminta untuk mencari dan menggunakan buku-buku penunjang atau melalui media. Hal ini sesuai dengan nilainilai gemar membaca yaitu kebiasaan menyediakan waktu untuk membaca berbagai bacaan yang memberikan kebajikan bagi dirinya.

\section{Peduli Lingkungan}

Nilai peduli lingkungan di SMP Negeri 1 Pangkalan Kuras dikembangkan dengan peduli kebersihan lingkungan sekolah, lingkungan kelas, serta membiasakan pola hidup bersih. Untuk menjaga kebersihan kelas siswa membuat jadwal piket dan dilaksanakan sesuai dengan jadwal masing-masing siswa. Sangsi akan diberikan apabila ada siswa yang tidak melaksanakan tugas membersihkan kelas yakni siswa diberi hukuman membersihkan kelas selama satu minggu.

Untuk selalu peduli lingkungan sekolah juga memasang slogan-slogan yang isinya mengajak siswa agar menjaga lingkungan serta kebesihan yang terpasang di tempat-tempat strategis dan loronglorong sekolah. Sekolah juga mengajak siswa menanam pohon dan diwajibkan memeliharannya. Hal ini terlihat dari lingkungan SMP Negeri 1 Pangkalan Kuras yang asri dan rindang.

\section{Peduli Sosial.}

Nilai peduli sosial di SMP Negeri 1 Pangkalan Kuras teritegrasi ke dalam mata pelajaran seperti siswa dibiasakan saling memberikan bantuan dalam hal kebaikan seperti meminjamkan alat-alat tulis kepada teman yang membutuhkan. Selain itu juga dikembangkan melalui pengumpulan infak oleh OSIS dan disumbangkan kepada keluarga yang mendapat musibah. Kondisi ini sesuai dengan nilai-nilai peduli sosial yaitu sikap dan tindakan yang selalu ingin memberi bantuan pada orang lain dan masyarakat yang membutuhkan.

\section{Tanggung Jawab}

Nilai tanggung jawab di SMP Negeri 1 Pangkalan Kuras di kembangkan melalui kegiatan sehari-hari di sekolah seperti: siswa melaksanakan tugas piket kelas secara rutin, siswa aktif menanam dan merawat bunga, serta membuang sampah pada tempatnya. Guru memberikan motivasi dan keteladanan sehingga diharapkan siswa akan termotivasi dan sadar akan tugas dan kewajibannya sebagai siswa.

Keadaan ini sesuai dengan nilainilai tanggung jawab yaitu sikap dan perilaku seseorang untuk melaksanakan tugas dan kewajibannya yang seharusnya dia lakukan terhadap diri sendiri, masyarakat, lingkungan, negara dan Tuhan Yang Maha Esa.

Pendidikan karakter di MTs AlQasimiyah Pangkalan Kuras

\section{Religius}

MTs Al-Qasimiyah Pangkalan Kuras adalah sekolah berbasis agama islam tentunya semua kegiatan pembelajaran sangat erat kaitannya dengan karakter yang berhubungan dengan Tuhan (religius). Sebagaimana visi MTs Al-Qasimiyah yakni terwujudnya MTs Al-Qasimiyah yang beriman dan bertaqwa, berahklak mulia, berkepribadian baik, berilmu, terampil dan mampu mengaktualisasikan diri di tengah masyarakat. Adapun pelaksanaan pendidikan karakter religius di MTs Al-Qasimiyah Pangkalan Kuras dilaksanakan dengan cara: terintegrasi ke dalam mata pelajaran, muatan lokal, 
kegiatan pengembangan diri, pembiasaan dalam keseharian di sekolah dan dirumah.

Pengembangan nilai religius terintegrasi ke dalam mata pelajaran dengan menyertakan nilai-nilai religius ke dalam silabus dan RPP pada setiap bidang studi dalam pembelajaran. Nilai religius juga dikembangkan melalui pelajaran Arab Melayu sebagai mata pelajaran muatan lokal. Pelajaran Arab Melayu merupakan muatan lokal khas Propinsi Riau. Selain itu nilai religius juga dikembangkan melalui sholat zuhur berjamaah, yasinan setiap jum'at pagi dan kultum setiap sabtu pagi. Nilai religius juga dilaksanakan melalui kegiatan muhadoroh yang sarat dengan kegiatan Islami dan memperingati hari besar Islam.

Selain itu nilai religius juga terlihat dari cara berpakaian siswa dimana siswi perempuan harus memakai jilbab dan siswa laki-laki memakai peci. Bagi siswa yang berurusan ke kantor majelis guru wajib mengetuk pintu dan mengucapkan salam terlebih dahulu.

Jujur

Pelaksanaan nilai jujur di MTs AlQasimiyah Pangkalan Kuras dikembangkan melalui terintegrasi ke dalam semua pelajaran. Misalkan dalam pemberian tugas, siswa tidak dibenarkan mencontek hasil kerja temannya. Sangsi akan diberikan guru apabila ketahuan mencontek. Sementara itu penyediaan sarana penemuan barang hilang dan kantin kejujuran merupakan salah satu indikator keberhasilan sekolah dalam mengembangkan nilai kejujuran siswa. Sekolah belum menyediakan tempat penemuan barang hilang dan belum mendirikan kantin kejujuran sebagai sarana pengembangan nilai kejujuran siswa. Namun demikian nilai kejujuran siswa pada umumnya sudah baik.

\section{Toleransi}

Nilai toleransi di MTs Al-Qasimiyah Pangkalan Kuras dikembangkan melalui terintegrasi ke dalam mata pelajaran.
Guru senantiasa memberikan keteladanan agar selalu menghargai dan memberikan perlakuan yang sama terhadap seluruh warga sekolah tanpa membeda-bedakan suku, ras, golongan, status sosial, status ekonomi, dan kemampuan khas. Hal ini sesuai dengan nilai-nilai toleransi ialah sikap dan tindakan yang menghargai perbedaan agama, suku, etnis, pendapat, sikap, dan tindakan orang lain yang berbeda dari dirinya.

\section{Disiplin}

Nilai disiplin di MTs Al-Qasimiyah Pangkalan Kuras dikembangkan melalui terintegrasi ke dalam mata pelajaran. Ini semua terlihat dari pengerjaan tugas yang diberikan guru agar diselesaikan dengan tepat waktu dan disiplin datang tepat waktu. Pengembangan disiplin juga dilaksanakan melalui pengkondisian dengan membuat tata krama dan peraturan disiplin, selain itu kepala sekolah, guru, dan pegawai tata usaha selalu memberikan keteladanan dengan menegakkan aturan disiplin. Nilai-nilai disiplin tersebut dikembangkan sekolah dan telah menjadi budaya sekolah.

Sementara itu dari hasil data dokumentasi yang diperoleh dilapangan menunjukkan bahwa, tingkat kehadiran guru dan siswa sangat baik. Selain itu dari hasil observasi menunjukkan bahwa telah di pasang slogan yang mengajak siswa agar selalu disiplin dan datang tepat waktu, seperti di depan pintu masuk kantor majelis guru terdapat slogan tepat waktu adalah cermin kepribadianku. Hal ini sesuai dengan nilai-nilai disiplin yaitu tindakan yang menunjukkan perilaku tertib dan patuh pada berbagai ketentuan dan peraturan.

\section{Kerja Keras}

Nilai kerja keras di MTs Al-Qasimiyah Pangkalan Kuras dikembangkan melalui terintegrasi ke dalam mata pelajaran. Salah satunya melalui dorongan semangat dan kerja keras kepada siswa dengan membiasakan menyelesaikan tugas secepat 
mungkin. Nilai keras juga dikembangkan ke dalam kegiatan ekstrakurikuler, terbukti dengan banyaknya prestasi yang diraih sebagai hasil kerja keras. Selain itu nilai kerja keras juga diwujudkan dalam bentuk slogan, yang ditempel di tempat strategis untuk mengajak siswa agar senantiasa bekerja keras.

Kreatif

Nilai kreatif di MTs Al-Qasimiyah Pangkalan Kuras dikembangkan melalui terintegrasi ke dalam pembelajaran yang mengajarkan siswa untuk memahami jenisjenis khat huruf Al-quran. Selain itu untuk berpikir logis dan kritis guru salalu memberikan keyakinan dan pemahaman terhadap pembelajaran yang didasari keimanan peserta didik. Nilai kreatif siswa juga dikembangkan melalui kegiatan ekstrakurikuler, diantaranya seni kaligrafi. Sekolah mendatangkan atau menyediakan tenaga profesional sebagai tenaga pengajar seni kaligrafi.

Berdasarkan hasil pengamatan di sekolah bahwa hasil karya kaligrafi siswa banyak ditempel di dinding-dinding. Ini semua sebagai wujud penghargaan dan apresiasi pihak sekolah kepada siswa yang telah kreatif dalam menghasilkan prestasi. Kondisi ini sesuai dengan nilai-nilai kreatif yaitu berpikir dan melakukan sesuatu untuk menghasilkan cara atau hasil baru dari sesuatu yang telah dimiliki dengan demikian siswa bisa menambah pengetahuan dan mengembangkannya menjadi sesuatu yang bermanfaat bagi dirinya dan orang lain.

Mandiri

Nilai mandiri telah dikembangkan di MTs Al-Qasimiyah Pangkalan Kuras melalaui terintegrasi ke dalam mata pelajaran. Salah satunya dalam pembelajaran praktikum. Guru berupaya menuntun siswa agar senantiasa mandiri dan tidak bergantung dengan orang lain. Sikap mandiri juga disampaikan guru saat siswa mengerjakan ulangan atau ujian, dimana siswa tidak boleh mencontek dan harus dikerjakan sendiri. Kondisi ini sesuai dengan nilai-nilai mandiri yaitu sikap dan prilaku yang tidak mudah tergantung pada orang lain dalam menyelesaikan tugastugas.

\section{Demokratis}

Nilai demokratis di MTs Al-Qasimiyah Pangkalan Kuras di kembangkan terintegrasi ke dalam mata pelajaran. Dalam proses pembelajaran dilakukan melalui diskusi kelompok. Setiap siswa harus mendengarkan dan menghargai pendapat siswa lainya. Sedangkan dalam kegiatan pengembangan diri, sekolah menggunakan sistem demokrasi dalam pemilihan pengurus kelas dan pemilihan pengurus OSIS. Hal ini sesuai dengan nilai-nilai demokratis yaitu cara berpikir, bersikap, dan bertindak yang menilai sama hak dan kewajiban dirinya dan orang lain.

Rasa Ingin Tahu

Pendidikan nilai ingin tahu di MTs Al-Qasimiyah Pangkalan Kuras melalui terintegrasi ke dalam mata pelajaran. Agar rasa ingin tahu siswa dapat tumbuh guru menciptakan pembelajaran yang menantang. Sekolah telah menyediakan sarana infomasi dan komunikasi antara lain: berlangganan media cetak dan tersedianya televisi. Dengan disediakannya sarana informasi ini siswa bisa cepat tahu tentang situasi luar, terutama dunia pendidikan dan akan bertambah pengetahuannya. Hal ini sesuai dengan nilai-nilai rasa ingin tahu yaitu sikap dan tindakan yang selalu berupaya untuk mengetahui lebih mendalam dan meluas dari sesuatu yang dipelajari, dilihat, dan didengar.

\section{Semangat Kebangsaan}

Nilai semangat kebangsaan di MTs Al-Qasimiyah Pangkalan Kuras dikembangkan melalui terintegrasi ke dalam mata pelajaran seperti: menggunakan bahasa Indonesia yang baik dan benar di lingkungan sekolah. Semangat kebangsaan juga dikembangkan melalui kegiatan rutin sekolah seperti upacara bendera yang 
dilaksanakan setiap hari senin dan upacara memperingati hari-hari besar kenegaraan. Dalam kegiatan ekstrakurikuler sekolah mengembangkan paskibra dan Rohani Islam dengan tujuan untuk meningkatkan semangat kebangsaan. Hal ini sesuai dengan nilai-nilai semangat kebangsaan yaitu cara berpikir, bertindak, dan berwawasan yang menempatkan kepentingan bangsa dan negara di atas kepentingan diri dan kelompoknya.

\section{Cinta Tanah Air}

Nilai cinta tanah air di MTs AlQasimiyah Pangkalan Kuras dikembangkan melalui pemasangan simbol-simbol kenegaraan seperti: pemasangan gambar presiden dan wakil presiden serta gambar burung garuda pancasila. Selain itu untuk menambah pengetahuan siswa tentang wilayah Indonesia, di setiap kelas telah terpasang peta Indonesia, peta propinsi dan peta kabupaten. Untuk mengetahui informasi tentang situasi Indonesia terbaru, sekolah menyediakan televisi, koran dan majalah. Hal ini sesuai dengan nilai-nilai cinta tanah air yaitu cara berpikir, bersikap, dan berbuat yang menunjukkan kesetiaan, kepedulian, dan penghargaan yang tinggi terhadap bahasa, lingkungan fisik, sosial, budaya, ekonomi, dan politik bangsa.

\section{Menghargai Prestasi}

Nilai menghargai prestasi di MTs Al-Qasimiyah Pangkalan Kuras dikembangkan terintegrasi ke dalam mata pelajaran. Guru selalu memberikan motivasi kepada siswa untuk berprestasi baik akademik maupun nonakademik. Sekolah dalam menghargai prestasi siswa telah memajang tanda-tanda penghargaan prestasi yang telah diraih siswa seperti piala, piagam dan mendali yang terpajang di ruang tamu, ruang kepala sekolah maupun ruang guru. Hal ini sesuai dengan nilainilai menghargai prestasi yaitu sikap dan tindakan yang mendorong dirinya untuk menghasilkan sesuatu yang berguna bagi masyarakat, mengakui, dan menghormati keberhasilan orang lain.
Bersahabat/ Komunikatif

Nilai bersahabat/komunikatif di MTs Al-Qasimiyah Pangkalan Kuras dikembangkan dengan keteladanan yang dilakukan kepala sekolah, guru dan pegawai seperti: senang berbicara, bergaul dan bekerjasama. Semua guru berbicara santun dan penuh keakraban serta penuh kasih sayang kepada semua siswa dan sesama guru. Selain itu guru juga mau menerima keluhan-keluhan yang disampaikan siswa, baik masalah pelajaran maupun masalah diluar pelajaran. Hal ini dilakukan selain untuk memberi keteladanan nilai bersahabat juga untuk kemajuan perkembangan aspek kognitif maupun psikomotorik siswa.

\section{Cinta Damai}

Nilai cinta damai di MTs Al-Qasimiyah Pangkalan Kuras dilakukan dengan menciptakan suasana sekolah dan iklim kerja yang nyaman, tentram dan harmonis. Selain itu sekolah juga membiasakan warganya untuk menghindari kekerasan, baik kekerasan fisik maupun mental. Kepala sekolah menindak tegas setiap kekerasan yang terjadi. Bagi pelaku kekerasan baik guru maupun siswa akan mendapat sangsi.

Kondisi ini sesuai dengan nilai-nilai cinta damai yaitu sikap, perkataan, dan tindakan yang menyebabkan orang lain merasa senang dan aman atas kehadiran dirinya. Selain itu pendidikan nilai cinta damai diharapkan bisa dihayati dan dimengerti oleh siswa sehingga bisa diterapkan dalam kehidupan sehari-hari peserta didik berperilaku cinta damai dan mau berbagi dengan teman-temannya, mau menunggu saat antri dengan penuh kesabaran dan tentunya tidak egois.

\section{Gemar Membaca}

Nilai cinta ilmu di MTs AlQasimiyah Pangkalan Kuras dikembangkan melalaui terintegrasi ke dalam mata pelajaran. Guru mendorong siswa untuk banyak membaca, melalui metode pemberian tugas baik kelompok maupun tugas 
mandiri. Selain itu siswa diminta untuk menggunakan buku referensi dari perpustakaan maupun buku yang didapat dari luar. Program gemar membaca juga didukung oleh Pemerintah Daerah melalui Dinas Pendidikan Kabupaten Pelalawan dengan menyediakan mobil perpustakaan keliling. Sekolah juga telah menyediakan berbagai koleksi buku, yang bisa dimanfaatkan siswa untuk menambah pengetahuannya. Hal ini sesuai dengan nilai-nilai gemar membaca yaitu kebiasaan menyediakan waktu untuk membaca berbagai bacaan yang memberikan kebajikan bagi dirinya.

\section{Peduli Lingkungan}

Nilai peduli lingkungan di MTs AlQasimiyah Pangkalan Kuras dikembangkan terintegrasi ke dalam mata pelajaran. Guru memberikan pemahaman tentang dampak kerusakan lingkungan akibat ulah manusia. Selain itu sekolah juga menumbuhkan rasa peduli siswa terhadap lingkungan sekolah seperti, menjaga kebersihan kelas dan membuang sampah pada tempatnya, menjaga tumbuh-tumbuhan dan merawatnya.

Sekolah juga mengkondisikan agar siswa bisa membuang sampah pada tempatnya dengan menyediakan tempattempat sampah yang letakkan didepan kelas maupun di tempat strategis. Hal ini sesuai dengan nilai-nilai peduli lingkungan yaitu sikap dan tindakan yang selalu berupaya mencegah kerusakan pada lingkungan alam di sekitarnya dan mengembangkan upaya-upaya untuk memperbaiki kerusakan alam yang sudah terjadi.

Peduli Sosial

Nilai peduli sosial di MTs AlQasimiyah Pangkalan Kuras teritegrasi ke dalam mata pelajaran seperti, siswa dibiasakan untuk saling memberikan bantuan dalam hal kebaikan. Selain itu peduli sosial juga dikembangkan melalui pengumpulan infak oleh OSIS. Hasil infak yang terkumpul akan disumbangkan kepada keluarga yang mendapat musibah maupun kepada anak yatim yang ada di Panti Asuhan. Kondisi ini sesuai dengan nilai-nilai peduli sosial yaitu sikap dan tindakan yang selalu ingin memberi bantuan pada orang lain dan masyarakat yang membutuhkan.

\section{Bertanggung Jawab}

Pelaksanaannya nilai tanggung jawab di MTs Al-Qasimiyah Pangkalan Kuras terintegrasi ke dalam mata pelajaran antara lain: melalui diskusi kelompok, piket kelas, membaca, menghapal Al-Qur'an dan Hadist serta mengerjakan pekerjaan/tugas lainnya sebagai bentuk nilai tanggung jawab masing-masing siswa. Keadaan ini sesuai dengan nilai-nilai tanggung jawab yaitu sikap dan perilaku seseorang untuk melaksanakan tugas dan kewajibannya, yang seharusnya dia lakukan, terhadap diri sendiri, masyarakat, lingkungan (alam, sosial dan budaya), Negara dan Tuhan Yang Maha Esa.

Berdasarkan pembahasan diatas, dapat dikatakan bahwa di MTs Al-Qasimiyah Pangkalan Kuras telah melaksanakan pendidikan karakter. Nilai-nilai tersebut dikembangkan melalui terintegrasi ke dalam mata pelajaran, pengembangan diri, keteladanan, budaya sekolah, maupun ekstrakurikuler dan pembiasaan.

\section{Simpulan dan Saran}

\section{Simpulan}

Pelaksanaan pendidikan karakter di SMP Negeri 1 dan MTs Al-Qasimiyah Pangkalan Kuras melaksanakan 18 nilai karakter kepada siswa yakni: religius, jujur, toleransi, disiplin, kerja keras, kreatif, mandiri, demokratis, ingin tahu, semangat kebangsaan, cinta tanah air, menghargai prestasi, bersahabat/komunikatif, cinta damai, gemar membaca, peduli lingkungan, peduli sosial, bertanggung jawab, melalui terintegrasi ke dalam mata pelajaran, pengembangan diri, budaya sekolah, kegiatan ekstrakurikuler, dan kegiatan keseharian di rumah dan masyarakat. Sedangkan perbedaannya terletak pada penanam- 
an nilai karakter bangsa di MTs AlQasimiyah lebih menitik beratkan kepada pendidikan keagamaan misalkan kultum, muhadoroh sebagai kegiatan ekstrakurikuler dan budaya sekolah yang agamis.

Saran

Berdasarkan hasil penelitian pelaksanaan pendidikan karakter di SMP Negeri 1 dan MTs Al-Qasimiyah Pangkalan Kuras maka dapat di sarankan:

1. Dinas pendidikan agar lebih meningkatkan sosialisasi dan pelatihan khususnya kepada guru yang belum pernah mengikuti pelatihan pendidik-an karakter, sehingga diharapkan semua guru dapat memahami dan mengimplementasikannya di sekolah.

2. Kepala sekolah agar senantiasa mendorong guru dalam mengimplementasikan pendidikan karakter kepada siswa khususnya guru yang belum perna diikutkan pelatihan meskipun pendidikan Akhlak sudah diterapkan di MTs Al-Qasimiyah.

3. Orang tua lebih proaktif ketika putra putrinya bermasalah atau bekerjasama dengan sekolah.

4. Guru dapat melakukan pendekatan dengan bersilaturahmi kerumah orang tua siswa terutama bagi siswa yang bermasalah.

5. Agar pelaksanaan pendidikan karakter berjalan sesuai yang diharapkan, maka hendaknya semua guru memberikan keteladanan kepada siswa.

Sarana untuk menunjang pendidikan karakter agar dapat ditingkatkan seperti sarana ibadah, sehingga seluruh warga sekolah dapat melaksanakan sholat berjamaah sebagai bagian nilai karakter.

\section{Daftar Pustaka}

Barnawi \& M. Arifin. (2012). Strategi dan kebijakan, pembelajaran pendidikan karakter. Yogyakarta: AR-Ruzz Media.

Deal. T. E \& Peterson. K. D. (1999). Shapping school culture. San Fransisco: Jassey-bass fiblishers.
Depdiknas. (2003). Undang-Undang RI Nomor 20, Tahun 2003, tentang Sistem Pendidikan Nasional.

Kemendiknas. (2010). Panduan pendidikan karakter di sekolah menengah pertama. .(2010). Pengembangan pendidikan budaya dan karakter bangsa pedoman sekolah.

(2010). Desain induk pendidikan karakter.

.(2011). Pedoman pelaksanaan pendidikan karakter (berdasarkan pengalaman di satuan pendidikan rintisan).

Koesoema A. D. (2007). Pendidikan karakter: strategi mendidik anak di zaman global. Jakarta: Grasindo.

Lahey, J. (2013). The benefits of character education. The atlantic. Diambil tanggal 26 Mei 2013, dari http:// www.theatlantic.com/national/arc hieve.

Moleong, L. J. (2006). Metodologi penelitian kualitatif.Bandung: PT Rosda Karya.

Miles, M. B. \& Huberman, A. M. (1994). Qualitative data analysis ( $2^{\text {nd }}$ ed): an expanded saurcebook. London: Sage Publication.

Noor, R.M. (2012). The hidden curiculum, membangun karakter melalui kegiatan ekstrakurikuler. Yogyakarta: Insan madani

Prastowo, A. (2012). Metode penelitian kualitatif: dalam perspektif rancangan penelitian. Yogyakarta: Ar-Ruzz Media

Zuchdi, D. (2011). Pendidikan karakter, dalam perspektif teori dan praktek. Yogyakarta: UNY Press.

Wibowo, A. (2012). Pendidikan karakter: strategi membangun karakter bangsa berkepribadian. Yogyakarta: Pustaka Pelajar 